Egypt. Acad. J. biolog. Sci., 2 (2): 147-164 (2009)

Email: egyptianacademic@yahoo.com

Received: 30/11/2009
A. Entomology

ISSN: 1687-8809

www.eajbs.eg.net

\title{
Influenced survival and development of the desert locust Schistocerca gregaria (acrididae) by the wild plant Fagonia bruguieri (zygophyllaceae).
}

Ghoneim, K. S.; Tanani, M. A. and Basiouny, A. L. Faculty of Science, Al-Azhar University Madenit Nasr, Cairo, Egypt

\section{ABSTRACT}

Three extracts were prepared from the wild plant Fagonia bruguieri: methanolic extract, petroleum ether extract and n-butanolic extract. These extracts were assessed against the penultimate and last instar nymphs of Schistocerca gregaria. After treatment of the penultimate instar nymphs, a dose-dependent trend of mortality could be observed for the methanolic extract. To some extent, a lesser toxic action was exerted on the nymphs by petroleum ether extract or n-butanolic extract. After treatment of the last instar nymphs, an ascending mortality \% was estimated as the concentration level of methanolic extract was increased.

After treatment of the penultimate instar nymphs, the growth of the same treated nymphs was affected to some extent by the methanolic extract, irrespective of the concentration level. The remarkably influenced nymphal growth was detected only at the highest concentration level of petroleum ether extract and the higher two concentration levels of n-butanolic extract. Also, the profoundly extended developmental duration was caused by petroleum ether extract at the higher three concentration levels. After treatment of the last instar nymphs, all extracts exhibited inhibitory effects on the growth because the nymphs were prohibited to gain somatic weights as their control congeners obtained. A fastening action of methanolic extract on the developmental rate along shortened developmental duration especially at the highest concentration level. In contrast, a retarding action on such rate of the developing nymphs was exerted by both the petroleum ether extract and n-butanolic extract. The Fagonia bruguieri extracts intervened in the metamorphosis program because some nymphal-adult intermediates were formed.

KeyWords: Schistocerca gregaria, Fagonia bruguieri, lethality, growth, development, nymph, weight gain, nymphal-adult intermediates,

\section{INTRODUCTION}

Along the last five decades, the most famous insecticides in the field of pest control fall within four main classes, the organochlorines, organophosphates, carbamates and pyrethroids. The major classes in use today are organophosphates and carbamates (Ware, 1982; Dorow, 1993). Because of the dangerous side effects of these insecticides on the environment and human health, the organochlorines has been banned in the developing countries and alternative agents are being investigating for the insect pest control (Franzen, 1993). Botanicals are a promising source of pest control compounds. Today over 2000 species of plants are known to possess some insecticidal activity (Jacobson, 1989). One plant species may possess substances with a wide range of activities, for example, extracts from the neem tree Azadirachta indica are antifeedant, antioviposition, repellent and growth-regulating (Schmutterer, 1995).

The botanical insecticides are generally pest-specific and are relatively harmless to non-target organisms including man. They are also biodegradable and 
harmless to the environment (Rembold, 1994). Furthermore, unlike conventional insecticides which are based on a single active ingredient, plant derived insecticides comprise an array of chemical compounds which act concertedly on both behavioural and physiological processes. Thus the chances of pests developing resistance to such substances are less likely (Saxena, 1987).

One of the most important plants is neem tree A. indica whose oil from seeds is now marketed as a pesticide (Ghoneim and Abdel-Ghaffar, 2007). In addition, nicotine from Nicotiana tobaccum (Sugavabam and Copping, 1998), pyrethroids from Chrysanthemum cinerariaefolium (Crosby, 1995) and rotenoids from the roots of leguminous plants, Lanchocarpous spp. , are used for controlling the destructive pests of both agriculture and health. Unfortunately, the pests are now developing resistance not only to the synthetic insecticides but also to synthetic natural prethroids and rotenoids. Hence it is necessary to search for novel plant-based pesticides that are more efficacious and environmentally friendly (Georges et al., 2006).

Invasions of the desert locust, Schistocerca gregaria, have been known as a severe threat to the agricultural crops in North Africa (Showler, 1995). Because of the difficulty to predict locust outbreaks, the concerned countries used some pollutant chemical insecticides for controlling this dangerous pest (Gruys, 1993). Several trials have been conducted for using alternatives to these insecticides. Within this concern, some plant extracts including those of Zygophyllum simplex and Calotropis procerae in Egypt (El-Gammal et al., 1988), , Eucalyptus gomphocephala in Algeria (Guendous-Benrima, 2005), A. indica in Mauritania (Boughdad et al., 2005) and Olea europea and Cestrum parquii in Tunisia (Barbouche, 2001; Ammar and N'cir, 2008) were tested against the desert locust nymphs. All these plant extracts revealed toxic or/and antifeedant effects on nymphs and were considered as effective in the control of S. gregaria. The aim of the present work was to examine the effect of the wild plant Fagonia bruguieri (Zygophyllaceae) on the survival potential, growth and development of $S$. gregaria.

\section{MATERIALS AND METHODS}

\section{I) Experimental Insect:}

The desert locust Schistocerca gregaria (Frosk.) (Orthoptera: Acrididae) was used as an experimental insect in the present study. The present culture was originated by a lot of gregarious nymphs obtained from Locust Research Division, Plant Protection Research Institute, Ministry of Agriculture, Doqqi, Giza. Insects were reared in wooden formed cages measuring: $60 \mathrm{~cm}$ length $\times 60 \mathrm{~cm}$ Width $\times 70 \mathrm{~cm}$ height. Three sides of the cage were made of wood and the fourth side was glass, with a wire gauze tope. The front side of the cage was provided with a small door to facilitate daily routine work and maintenance of the insects. The bottom was furnished with a sandy layer of $20 \mathrm{~cm}$ depth and with $10-15 \%$ humidity to be suitable for egg laying. An electric bulb (100 watt) was adjusted to maintain a continuous photoperiod of $12 \mathrm{~L}: 12 \mathrm{D}$ in each cage as well as in order to maintain an ambient temperature of $32 \pm 2^{\circ} \mathrm{C}$.

The insects were reared and handled under the crowded conditions outlined by Hunter-Jones (1961). Half hundred adults were placed in each cage for egg laying. The feces, dead locusts and food remains were removed daily before introducing the freshly food. Care was seriously taken to clean these cages at regular intervals and the sand was sterilized in drying oven (at $140^{\circ} \mathrm{C}$ for 24 hours) to avoid contamination with any pathogenic microorganisms. Fresh clean leaves of berseem Medicago sativa, 
in winter, and the leaves of leguminous plant Sesbania aegyptiaca, in summer, were used as a food for insects. On the other hand, the berseem leaves only were offered as food for insects during the experimental work.

\section{II) Plant extracts:}

Fagonia bruguieri var. bruguieri is a perennial wild plant distributed all deserts in Egypt but profusely spread in Sinai. It is, also, distributed in Arabia, Jordon, Syria, Iraq, Palestine, Iran, Pakistan, Afghanistan and North Africa. It systematically belongs to family Zygophyllaceae. The aerial parts of the plant (leaves, stems and flowers) were collected from the region of Santa Catherin (Sinai) during flowering stage, and kindly identified by Dr. Abdo marey, Faculty of Science, Al-Azhar University (Cairo). The collected samples were air-dried, powdered and kept in tightly closed amber coloured glass containers for protecting from light, at low temperature.

Dried and pulverized powder of $F$. bruguieri $(2 \mathrm{~kg})$ was exhaustively separately extracted with methanol $(1.7 \mathrm{Lx} 3)$. The combined alcohol extracts were concentrated to $400 \mathrm{ml}$, diluted with $400 \mathrm{ml}$ of water and the next successively extracted with petroleum ether $(5 \times 400 \mathrm{ml})$ was concentrated to dryness under reduced pressure giving $(80 \mathrm{~g})$, while $\mathrm{n}$-butanol $(5 \mathrm{x} 400 \mathrm{ml})$ extracts were concentrated to dryness under reduced pressure giving ( $60 \mathrm{~g})$.

\section{III) Nymphal treatments:}

The used concentration levels of the methanolic extract were: $15,7.5,3.7 \&$ $1.8 \%$ but of the petroleum ether extract and n-butanolic extract were: $30.0,15.0,7.5$, $3.7 \& 1.8 \%$.

The newly moulted $4^{\text {th }}$ (penultimate), or $5^{\text {th }}$ (last) instar nymphs of S. gregaria were fed on fresh leaves of $M$. sativa after dipping in the different concentration levels of each extract. After dipping for three minutes, the treated leaves were allowed to dry before offering to the nymphs. A day after treatment, all nymphs (treated and control) were provided with untreated fresh food plant. Ten replicates (one nymph/replicate) were used for each concentration. Each individual nymph was isolated in a glass vial provided with a thin layer of sterilized sand as a floor. All vials were located in a large cage having a suitable electric bulb. After feeding for $24 \mathrm{hrs}$ on the treated leaves, the nymphs were carefully weighed every day using a digital balance and also examined for recording the mortality and different observations.

\section{IV) Survival, Growth and Development:}

All mortalities, of treated and control insects, were recorded after $24 \mathrm{~h}$ postfeeding. The weight gain was calculated as follows:

Initial weight (before the beginning of experiment) - final weight (at the end of experiment).

Dempster's equation (1957) was applied for calculating the developmental duration, and Richard's equation (1957) was used for calculating the developmental rate.

\section{V) Statistical Analysis of Data:}

Data obtained were analyzed by the Student's $t$-distribution, and refined by Bessel correction (Moroney, 1956) for the test significance of difference between means.

\section{RESULTS}

The wild plant Fagonia bruguieri were extracted by the organic solvents: methanol, petroleum ether and n-butanol. Five concentration levels of each extract $(15.0,7.5,3.7,1.8$ and $0.9 \%)$ were applied against the early penultimate or last instar 
nymphs of $S$. gregaria through the fresh clover leaves Trifolium alexandrenum. After the first $24 \mathrm{~h}$, the following results were recorded.

1) Lethal Effects of F. bruguieri on S. gregaria:

a) After treatment of the penultimate instar nymphs :

As illustrated in Fig. (1A), the penultimate instar nymphs completely died at the highest concentration level of methanolic extract while a dose-dependent trend of mortality could be observed among other treated nymphs. To some extent, a lesser toxic action was exerted on the penultimate instar nymphs by petroleum ether extract. Moreover, at only the higher two concentration levels of n-butanolic extract 30 and $20 \%$ mortality were estimated (in comparison with $10 \%$ natural mortality). At the lower concentration levels of it, no mortality was recorded.

The successfully moulted last instar nymphs were subjected to a lethal effect of these F. bruguieri extracts (Fig. 1A). After treatment with methanolic or petroleum ether extract, the mortality $\%$ was proportional to the concentration level while only 28.5 and $12.5 \%$ of mortality were observed at the higher two concentration levels of n-butanolic extract but no mortality was observed after treatment with other concentration levels.

\section{b) After treatment of the last instar nymphs :}

Fig. (1B) clearly demonstrates various degrees of the lethal effect on nymphs after treatment of the last instar nymphs. No significant mortality among nymphs could be observed after treatment with the lower three concentration levels of $n$ butanolic extract or petroleum ether extract. On the contrary, an ascending mortality $\%$ was estimated as the concentration level of methanolic extract was increased.
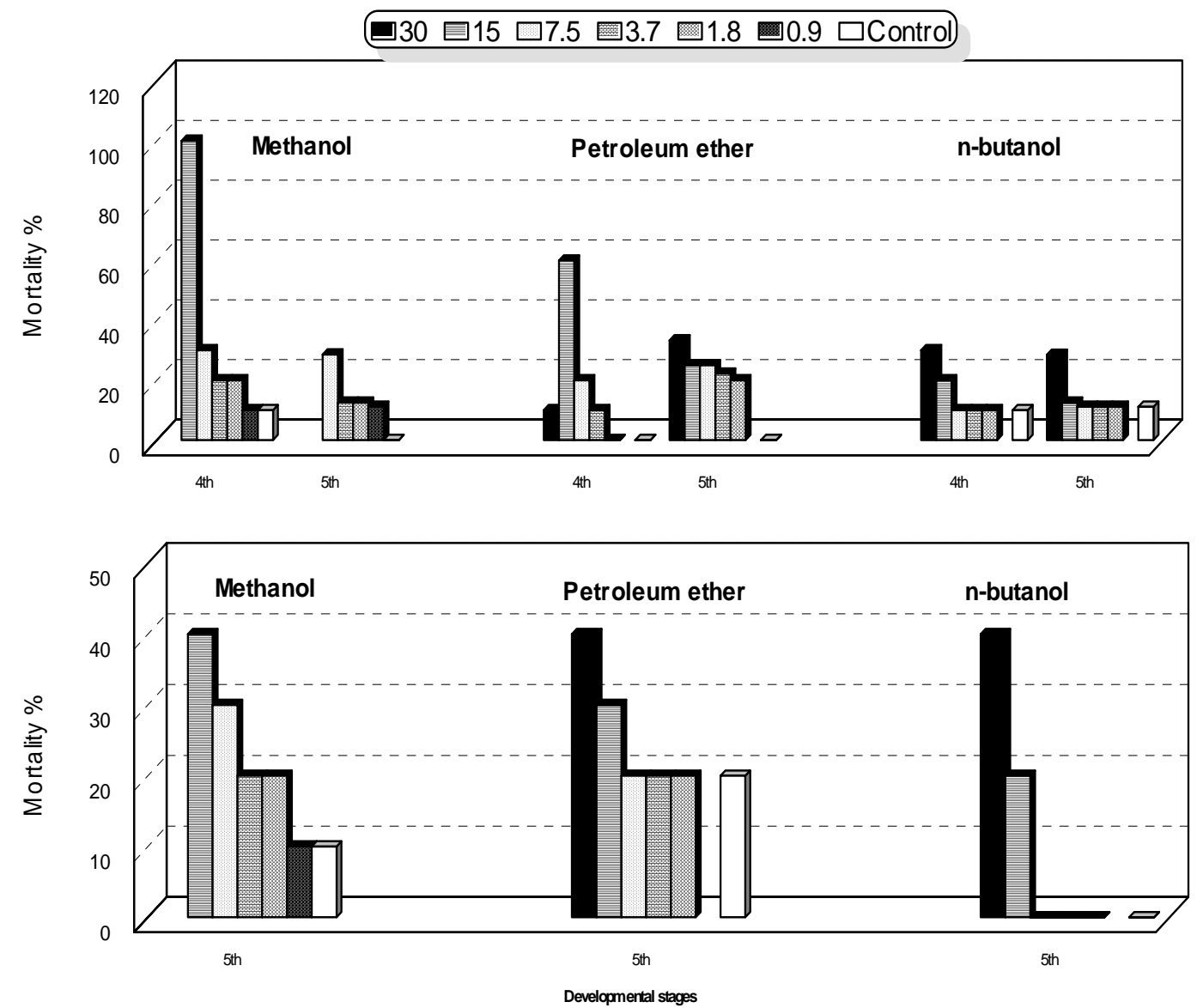

(B)

Fig.(1): Lethal effect (\%) of Fagonia bruguieri extracts on the nymphs of desert locust Schistocerca gregaria after treatment of early penultimate instar nymphs (A) or last instar nymphs (B). 


\section{2) Growth and Developmental Effects of Fagonia bruguieri Extracts:}

a) After treatment of the penultimate instar nymphs:

After treatment of the penultimate instar nymphs, the growth of the same treated nymphs was affected to some extent because no pronouncedly decreased weight gain was recorded by the methanolic extract, irrespective of the concentration level (see Fig. 2 I). The remarkably influenced nymphal growth was detected only at the highest concentration level of n-butanolic extract $(275.6 \pm 58.3 \mathrm{mg}$ at concentration level $30 \%$, compared to $332.7 \pm 26.7 \mathrm{mg}$ of control nymphs) and the higher two concentration levels of petroleum ether extract $(289.6 \pm 55.8$ and $289.0 \pm 43.9 \mathrm{mg}$ at concentration levels 30.0 and $15.0 \%$, compared to $361.1 \pm 53.8 \mathrm{mg}$ of control nymphs).

In the light of data arranged in Table (1), methanolic extract of $F$. bruguieri failed to significantly affect the developmental duration except at only the highest concentration level where the developmental duration was prolonged $(10.4 \pm 1.6$ days at concentration level $7.5 \%$, vs. $08.7 \pm 1.4$ days of control nymphs) and subsequently the developmental rates were slower than that of control nymphs. Also, the profoundly extended developmental duration was caused by petroleum ether extract only at the higher three concentration levels $(12.2 \pm 2.3,11.5 \pm 1.2$ and $11.6 \pm 1.2$ days at concentration levels $30.0,15.0$ and $7.5 \%$, in comparison with $9.7 \pm 1.7$ days of control nymphs). Thus, slower developmental rates were recorded at these concentration levels. No significant delay of the developmental duration was exhibited by the nbutanolic extract because slightly slowed down developmental rate was attained.

Table (1): Developmental effects of Fagonia bruguieri extracts on the desert locust Schistocerca gregaria after treatment of the early penultimate instar nymphs.

\begin{tabular}{|c|c|c|c|c|c|c|}
\hline \multirow[b]{2}{*}{ 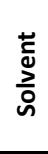 } & \multirow[b]{2}{*}{$\begin{array}{l}\text { Conc. } \\
\text { (\%) }\end{array}$} & \multicolumn{2}{|c|}{$4^{\text {th }}$ instar } & \multicolumn{3}{|c|}{$5^{\text {th }}$ instar } \\
\hline & & $\begin{array}{c}\text { Duration } \\
\text { (Mean day } \pm \\
\text { SD) }\end{array}$ & $\begin{array}{l}\text { Develop. } \\
\text { rate }\end{array}$ & $\begin{array}{c}\text { Duration } \\
\text { (Mean day } \pm \\
\text { SD) }\end{array}$ & $\begin{array}{l}\text { Develop. } \\
\text { rate }\end{array}$ & $\begin{array}{l}\text { Nymphal- } \\
\text { Adult Inter. } \\
(\%)\end{array}$ \\
\hline \multirow{6}{*}{ 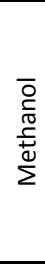 } & 15.0 & --- & --- & --- & --- & --- \\
\hline & 07.5 & $10.4 \pm 1.6 b$ & 9.5 & $13.0 \pm 1.0 \mathrm{~b}$ & 7.7 & 14.3 \\
\hline & 03.7 & $09.5 \pm 1.9 \mathrm{a}$ & 10.5 & $11.1 \pm 2.0 \mathrm{a}$ & 8.9 & 12.5 \\
\hline & 01.8 & $09.1 \pm 1.3 \mathrm{a}$ & 11.0 & $11.0 \pm 1.9 \mathrm{a}$ & 9.1 & 0.0 \\
\hline & 00.9 & $08.5 \pm 1.6 \mathrm{a}$ & 11.8 & $11.1 \pm 1.5 \mathrm{a}$ & 9.0 & 0.0 \\
\hline & Controls & $08.7 \pm 1.4$ & 11.5 & $11.2 \pm 1.8$ & 8.9 & 0.0 \\
\hline \multirow{6}{*}{ 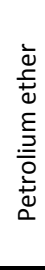 } & 30.0 & $12.2 \pm 2.3 b$ & 8.2 & $13.5 \pm 1.0 \mathrm{a}$ & 7.4 & 37.5 \\
\hline & 15.0 & $11.5 \pm 1.2 \mathrm{~b}$ & 8.7 & $13.5 \pm 0.7 \mathrm{a}$ & 7.4 & 22.2 \\
\hline & 07.5 & $11.6 \pm 1.2 b$ & 8.6 & $13.3 \pm 1.2 \mathrm{a}$ & 7.5 & 25.0 \\
\hline & 03.7 & $09.7 \pm 1.9 \mathrm{a}$ & 10.3 & $13.0 \pm 1.4 \mathrm{a}$ & 7.7 & 20.0 \\
\hline & 01.8 & $09.7 \pm 2.0 \mathrm{a}$ & 10.3 & $13.0 \pm 2.9 \mathrm{a}$ & 7.7 & 11.1 \\
\hline & Controls & $09.7 \pm 1.7$ & 10.3 & $11.9 \pm 1.5$ & 8.4 & 0.0 \\
\hline \multirow{6}{*}{ 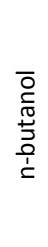 } & 30.0 & $10.4 \pm 2.7 a$ & 9.6 & $10.2 \pm 2.5 a$ & 9.8 & 0.0 \\
\hline & 15.0 & $10.8 \pm 1.8 \mathrm{a}$ & 9.3 & $10.3 \pm 2.4 \mathrm{a}$ & 9.7 & 12.5 \\
\hline & 07.5 & $09.8 \pm 2.2 \mathrm{a}$ & 10.2 & $10.6 \pm 1.3 \mathrm{a}$ & 9.4 & 0.0 \\
\hline & 03.7 & $09.9 \pm 2.3 \mathrm{a}$ & 10.1 & $10.1 \pm 2.7 a$ & 9.9 & 0.0 \\
\hline & 01.8 & $09.7 \pm 1.8 \mathrm{a}$ & 10.3 & $10.2 \pm 2.4 \mathrm{a}$ & 9.8 & 0.0 \\
\hline & Controls & $09.6 \pm 2.1$ & 10.4 & $11.0 \pm 1.9$ & 9.1 & 0.0 \\
\hline
\end{tabular}

Conc.: concentration, mean \pm SD followed with the same letter (a): is not significantly different $(\mathrm{P}>0.01)$, (b): significantly different $(\mathrm{P}<0.05)$, (c): highly significantly different $(\mathrm{P}<0.01)$, (d): very highly significantly different $(\mathrm{P}<0.001)$, Inter: intermedite, Develop. rate: Developmental rate.

Growth of the successfully moulted last instar nymphs were affected by the $F$. bruguieri extracts, to some extent, as exiguously shown in Fig. (2 I). The methanolic extract exhibited no inhibitory effect on the nymphal growth since the weight gain did not significantly decreased. On the other hand, the depressed weight gain, and 
subsequently prohibited growth, was unambiguously seen in the nymphs after treatment with petroleum ether extract (at the higher two concentration levels) and with n-butanolic extract (at only the highest concentration level). In addition, an evidently prolonged developmental duration was resulted by methanolic extract, at only the highest concentration level $(13.0 \pm 1.0$ days at concentration level $7.5 \%$, in comparison with $11.2 \pm 1.8$ days of control nymphs, Table 1), but other concentration levels led to insignificantly shortening of such duration indicating for the effect on the developmental rate which was found slower at the highest concentration level but little faster at other concentration levels. Also, not pronouncedly retarded growth was caused by the petroleum ether extract because not significant slow developmental rate was attained. On the contrary, no significantly accelerated developmental rate was recorded after treatment with n-butanolic extract since no significantly prolonged developmental duration was observed, irrespective of the concentration level.

The most effective F. bruguieri extract on the metamorphosis program was the petroleum ether one since the nymphal-adult intermediate creatures appeared in a dose-dependent trend and are clearly shown in Plate (1). More or less, similar inhibition of the S. gregaria metamorphosis was observed only at two concentration levels of methanolic extract (14.3 and $12.5 \%$ at concentration levels 7.5 and $3.7 \%$ ) and one concentration level of n-butanolic extract $(12.5 \%$ at concentration level $15.0 \%$, Table 1$)$.

b) After treatment of the last instar nymphs:

Data illustrated in Fig. (2 II) displayed the disruptive effects of F. bruguieri extracts on the growth of $S$. gregaria after treatment of the last instar nymphs.

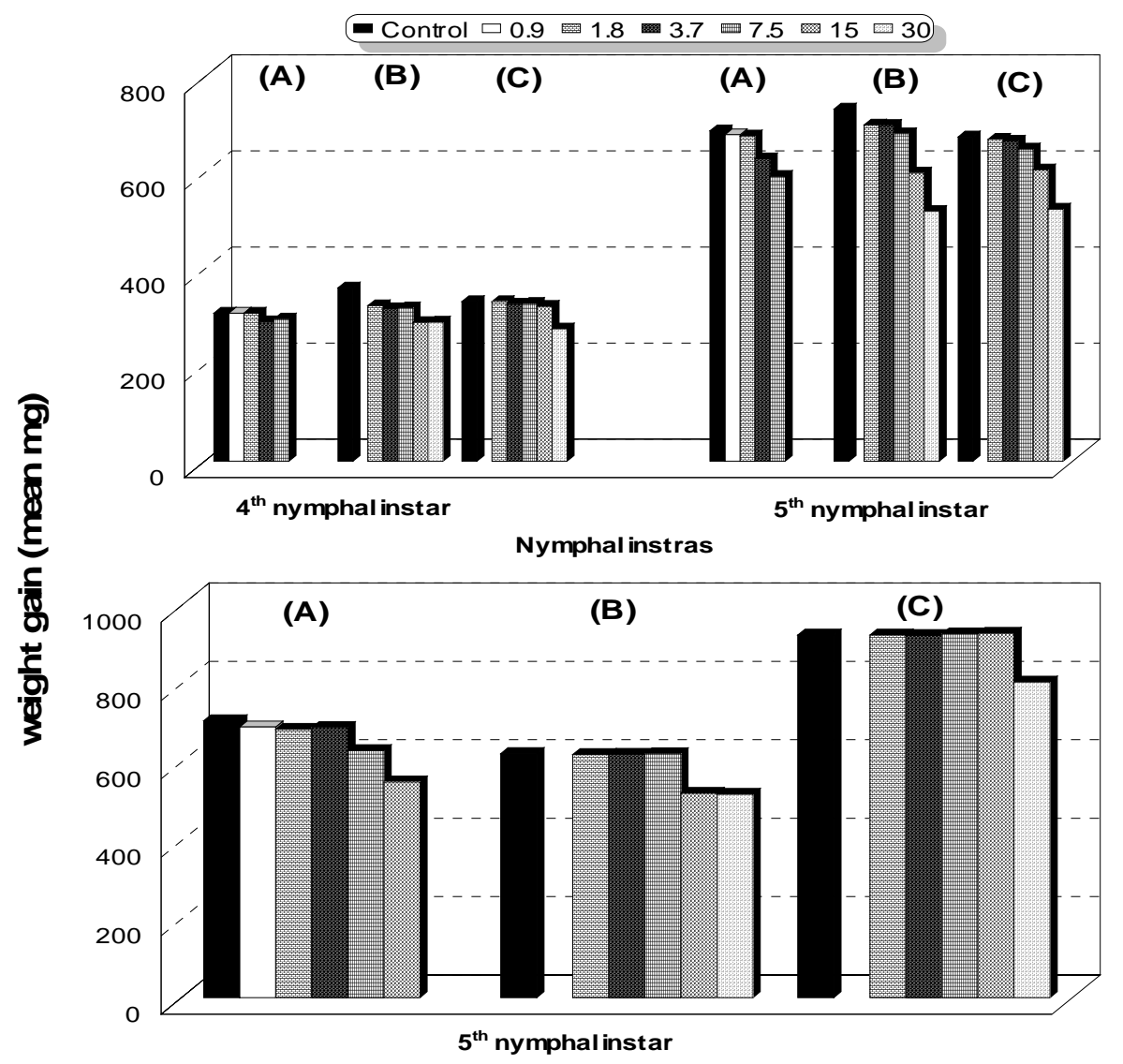

(l)

(II)

Fig. ( 2 ): Weight gains of the 4th and 5th instar nymphs of Shestocerca gregaria after treatment of early 4th (I) and early 5th (II) instar nymphs with Fagonia bruguieri extracts: methanol (A), petroleum (B) and n-butanol (C). 
All extracts exhibited inhibitory effects on the growth because the nymphs were prohibited to gain somatic weights as their control congeners obtained. For some details, the nymphal growth was significantly affected at the highest concentration level of methanolic extract where the weight gain remarkably declined $(550.0 \pm 140.2$ mg at concentration level $15.0 \%$, compared to $706.3 \pm 126.5 \mathrm{mg}$ of control congeners). Similarly, at the highest concentration level of n-butanolic extract $(804.7 \pm 110.3 \mathrm{mg}$ at concentration level $30.0 \%$, compared to $924.5 \pm 97.7 \mathrm{mg}$ of control congeners), the weight gain pronouncedly decreased indicating for significantly retarded growth. At the higher two concentration levels of petroleum ether extract, the nymphal growth was exiguously halted since the weight gain was considerably depleted $(518.3 \pm 42.2$ and $520.8 \pm 25.7 \mathrm{mg}$ at concentration levels 30.0 and $15.0 \%$, in comparison with $622.3 \pm 30.3$ of control congeners, see Fig. 2 II ).

Data arranged in Table (2) reveal a fastening action of methanolic extract on the developmental rate along shortened developmental duration especially at the higher two concentration levels $(5.7 \pm 1.9$ and $6.3 \pm 2.1$ daya at concentration levels 15.0 and $7.5 \%$, compared to $9.6 \pm 1.5$ days of control congeners) . In contrast, a retarding action on such rate of the developing nymphs was exerted by both the petroleum ether extract and n-butanolic extract. Whereas only the highest concentration level of nbutanolic extract retarded the developmental rate, treatment with all concentration levels of petroleum ether extract resulted in detrimentally interrupted rate along considerably lengthened duration.

Table (2): Developmental effects of the Fagonia bruguieri extracts on the desert locust Schistocerca gregaria after treatment of the early last instar nymphs.

\begin{tabular}{|c|c|c|c|c|}
\hline \multirow{2}{*}{ 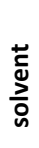 } & \multirow[b]{2}{*}{$\begin{array}{l}\text { Conc. } \\
\text { (\%) }\end{array}$} & \multicolumn{3}{|c|}{$5^{\text {th }}$ instar } \\
\hline & & $\begin{array}{c}\text { Duration } \\
\text { (Mean days } \pm \text { SD) }\end{array}$ & Develop. rate & $\begin{array}{l}\text { Nymphal- Adult } \\
\text { Inter. (\%) }\end{array}$ \\
\hline \multirow{6}{*}{ 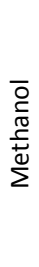 } & 15.0 & $5.7 \pm 1.9 d$ & 17.5 & 20.0 \\
\hline & 07.5 & $6.3 \pm 2.1 c$ & 15.9 & 20.0 \\
\hline & 03.7 & $8.6 \pm 1.7 \mathrm{a}$ & 11.6 & 10.0 \\
\hline & 01.8 & $9.2 \pm 1.3 \mathrm{a}$ & 10.9 & 10.0 \\
\hline & 00.9 & $9.1 \pm 2.0 \mathrm{a}$ & 11.0 & 10.0 \\
\hline & Controls & $9.6 \pm 1.5$ & 10.4 & 0.0 \\
\hline \multirow{6}{*}{ 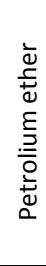 } & 30.0 & $12.0 \pm 1.0 \mathrm{~d}$ & 08.3 & 10.0 \\
\hline & 15.0 & $12.2 \pm 1.5 \mathrm{~d}$ & 08.2 & 10.0 \\
\hline & 07.5 & $12.5 \pm 1.2 \mathrm{~d}$ & 08.0 & 00.0 \\
\hline & 03.7 & $11.4 \pm 1.2 \mathrm{~d}$ & 08.8 & 00.0 \\
\hline & 01.8 & $11.2 \pm 1.1 \mathrm{~d}$ & 08.9 & 00.0 \\
\hline & Controls & $08.6 \pm 0.7$ & 11.6 & 00.0 \\
\hline \multirow{6}{*}{ 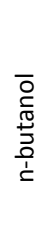 } & 30.0 & $11.8 \pm 1.5 b$ & 8.5 & 10.0 \\
\hline & 15.0 & $10.3 \pm 1.7 \mathrm{a}$ & 9.7 & 20.0 \\
\hline & 07.5 & $10.3 \pm 1.1 \mathrm{a}$ & 9.7 & 10.0 \\
\hline & 03.7 & $10.3 \pm 1.3 \mathrm{a}$ & 9.7 & 10.0 \\
\hline & 01.8 & $10.1 \pm 1.2 \mathrm{a}$ & 9.9 & 10.0 \\
\hline & Controls & $10.1 \pm 1.3$ & 9.9 & 00.0 \\
\hline
\end{tabular}

Conc.: See footnote of Table ( 1 ).Develop. rate, Inter, a, b, c, d: See footnote of Table (1).

In addition to the effect of $F$. bruguieri extracts on the nymphal growth and development, they intervened in the metamorphosis program because the data of the same table show some nymphal-adult intermediates. Such inhibited metamorphosis can be easily seen because the methanolic extract and n-butanolic extract led to the formation of 
nymphal-adult intermediates at all concentration levels but petroleum ether extract caused similar features only at the higher two concentration levels (Plate 1).

\section{DISCUSSION}

\section{1) Lethal potency of F. bruguieri on S. gregaria:}

So many reports about the toxicity of several extracts from different plant species belonging to various families were available in the literature. One of the most famous plants is the neem tree Azadirachta indica (Meliaceae) from which many extracts and preparations are obtained and assessed against different insect pests. Azadirachtin (Azt.), a seed kernel extract has a lethal activity against various insects as reported for Nilaparvata lugens (Saxena and Khan, 1985; Senthil Nathan et al., 2007); Haematopia irritans and Stomoxys calcitrans (Miller and Chamberlain, 1989); Schistocerca gregaria (Schmutterer and Freres, 1990; Nicol and Schmutterer, 1991; Osman, 1993); Nomadacris septemfasciata and Zonocercus variegates (Scnmutterer et al., 1993); Spodoptera exigua (Yoshida and Toscano, 1994); Trialeurodes vaporariorum (von Elling et al., 2002); Cnaphalocrocis medinalis (Senthil Nathan et al., 2006); Rhynchophorus ferrugineus (Abdel-Ghaffar et al., 2008); Chrysomia megacephala (Siriwattanarungsee et al., 2008); etc... Also, some other neem extracts, such as Margosan-0 and Neemazal, exhibited mortal effects on Earias insulana (Meisner et al., 1981), Ostrinia nubilalis (Meisner et al., 1991), Archips rosanus (AliNiazee et al., 1997), Musca domestica (Ghoneim and Al-Dali, 2002), Spodoptera littoralis (Ghoneim et al., 2000), Chrysomya chloropyga (Muse et al., 2003), Tribolium castaneum (Athanassiou et al., 2005).

In addition to the neem extracts, several plant species exhibited a toxicity against different insect species such as Azadirachta indica, Petiveria alliacea and Piper guineense against Zonocerus variegates (Olaifa and Akinghohungbe, 1986), Melia azaderach against Locusta migratoria migratorioides (Wen and Schmutterer, 1991), Leonuvus sibiricus leaves, Cyanchum wilfordii roots and Astragalus membranaceus roots against Lymantria dispar, Acantholyda porticalis and Hyphantria cunea (Benaag et al., 1997), Chukrasia tabularis var. velutina and Swietenia macrophylla against Oxya chinesis (Xiao Dong et al., 1997), Ageratum conyzoides against S. gregaria (Sharda et al., 2000), Cyprus rotendus against S. gregaria (El-Sokkary, 2003), Dysoxylum malabaricum against Anopheles stephensi (Senthil Nathan et al., 2006), Jojoba oil against Rh. ferrugineus (Abdel-Ghaffar et al., 2008), Centaurium erythreae, Peganum harmala, Ajuga iva, Aristolochia baetica, Pteridium aquilinum and Raphanus raphanistrum against Tribolium castaneum (Jbilou et al., 2008), etc...

In the present study, F. bruguieri exhibited a toxic activity against $S$. gregaria. After treatment of the penultimate instar nymphs, a dose-dependent trend of the nymphal mortality could be observed for the methanolic extract. To some extent, a lesser toxic action was exerted on the nymphs by petroleum ether extract or nbutanolic extract. After treatment of the last instar nymphs, an ascending mortality pecentage was estimated as the concentration level of methanolic extract was increased.

However, these lethal effects of $F$. bruguieri extracts on the nymphs of $S$. gregaria, in the present study, may be attributed to the feeding inhibition which usually leads to continuous starvation and subsequently death (Ghoneim et al., 2000) or to the inability of the moulting nymphs to swallow sufficient volumes of air to split the old cuticle and expand the new one during ecdysis (Mordue and Evans, 1987; 
Linton et al., 1997). In addition, the deaths of last instar nymphs of $S$. gregaria may be due to a metamorphosis inhibiting effect of the F. bruguieri extracts, which is possibly based on the disturbance of the hormonal regulation (Al-Sharook et al., 1991) because the prevention of the metamorphosing ecdysis, and subsequently death, could be attributed to the reduction in ecdysteroid peak or interference with the release of eclosion hormone (Sieber and Rembold, 1983). A further investigation should be carried out in future to explore the specific secondary metabolites, alkaloids or other active components, in the F. bruguieri extracts, which cause the disturbance or imbalance of the enzymatic pattern or hormonal hierarchy responsible for the maintenance of life of $S$. gregaria.

\section{2) Disturbed Growth and Development of S. gregaria:}

Because the body weight, and hence the weight gain, is one of the indicators for evaluating growth (Armbruster and Hutchinson, 2002), the weight gain of S. gregaria nymphs was determined in the present study. After treatment of the penultimate instar nymphs with $F$. bruguieri, the growth of the same treated nymphs was affected to some extent by the methanolic extract, irrespective of the concentration level. The remarkably inhibited nymphal growth was detected only at the highest concentration level of petroleum ether extract $(30.0 \%)$ and the higher two concentration levels of n-butanolic extract $(30.0 \% \& 15.0 \%)$. In addition, all extracts exhibited inhibitory effects on the growth after treatment of the last instar nymphs since they were prohibited to attain somatic weights as their control congeners.

The present inhibited growth, however, agree with the results reported for Azt. or other neem preparations against various insect species such as Phormia and Musca (Wilps, 1986), Spodoptera mauritia (Jagannadh and Nair, 1992), S. littoralis (Ghoneim et al., 2000), Diaprepes abbreviates (Weathersbee III and Tang, 2002), Muscina stabulans (Al-Dali et al., 2003), Musca domestica (Amer et al., 2004), N. lugens (Senthil Nathan et al., 2007), C. megacephala (Siriwattanarungsee et al., 2008) and Rh. ferrugineus (Abdel-Ghaffar et al., 2008). Also, extracts from some other plants inhibited the growth of different insects such as Sitophilus zeamais and Tribolium castaneum by essential oils of garlic ( Huang et al., 2000), T. castaneum by various compounds of $A$. pubescensi (Nascimento et al., 2004), Trichoplusia ni by some extracts from Melia volkensii (Akhtar and Isman, 2004), Spodoptera frugiperda and Tenebrio molitor by extracts from the roots and aerial parts of $M$. geometrizans (Cespedes et al., 2005), S. littoralis by Trichilia americana extracts (Senthil Nathan, 2006), C. medinalis by M. azadirach extracts (Senthil Nathan, 2006) and Rh. ferrugineus by Jojoba oil (Abdel-Ghaffar et al., 2008).

Generally, the growth inhibition in S. gregaria by the action of F. bruguieri extracts, in the present study, may be a result of the blocked release of morphogenic peptides, causing alteration in ecdysteroid and juvenoid titers (Sieber and Rembold, 1983; Linton et al., 1997). Also, some possible direct effects of F. bruguieri extracts on tissues and cells undergoing mitosis may have occurred (Nasiruddin and Mordue, 1994).

Beside the inhibited growth of $S$. gregaria, in the present study, the development was retarded by the action of $F$. bruguieri extracts because the developmental duration was significantly prolonged by the petroleum ether extract, at the higher three concentration levels $(30.0,15.0$ and $7.5 \%)$, after treatment of the penultimate instar nymphs. On the contrary, treatment of the last instar nymphs with methanolic extract resulted in remarkably shortened developmental duration indicating an enhanced development of the nymphs especially at the highest concentration level $(15.0 \%)$ while the petroleum ether and n-butanolic extracts 
exerted a retarding action since the developmental duration was pronouncedly prolonged.

The present results of retarded development in the desert locust $S$. gregaria by F. bruguieri are in accordance with several results reported for various insects by the action of extracts from different plants. Similar inhibitory effects of Azt. or other neem products were observed in L. migratoria (Urishalom et al., 1988), S. gregaria (Nicol and Schmutterer, 1991), S. mauritia (Jagannadh and Nair, 1992), S. exigua (Yoshida and Toscano, 1994), Spilostothus ponchrus (El-Sherif, 1998), M. domestica (Mohamed et al., 2000), S. littoralis (Ghoneim et al., 2000), Trialeurodes vaporariorum (von Elling et al., 2002), and in M. stabulans (Al-Dali et al., 2003).

The exceptional promoting effect of the methanolic extract from F. bruguieri on the development of S. gregaria, in the present study, after treatment of only the last instar nymphs agrees with similar effects of some other plant species on different insects, such as A. stephensi by Annona squamosa extracts (Saxena et al., 1993), Neobellieria bullata by Ajuga reptans reptans extracts (Darvas et al., 1996), M. domestica by Neemazal (Amer et al., 2004), Rh. ferrugineus by Azt. (Abdel-Ghaffar et al., 2008), and T. castaneum by extracts from Launaea arborescens and Pteridium aqilinum (Jbilou et al., 2008). Moreover, no effect on the developmental duration or rate was reported for some plant species such as M. volkensii on Culex pipiens (AlSharook, 1991) and Jojoba oil on M. domestica (Amer et al., 2004).

The major retarding effect of the $F$. bruguieri extracts on the development of S. gregaria, in the present study, can be explicated by the delaying effects of the plant extracts on the ecdysis and transformation of S. gregaria (Quadri and Nasralah, 1978; Linton et al., 1997). On the other hand, the exceptional inducing effect of methanolic extract from F. bruguieri on the development of S. gregaria may be due to a specific physiological elasticity in the insect body for overcoming the adverse conditions (like the action of some disturbing factors in the extract ) by shortening the time interval during which the insect would be more tolerant.

\section{3) Disrupted Metamorphosis of S. gregaria:}

The nymphal-adult transformation program of different insects was affected by various botanicals as reported for $S$. gregaria after nymphal treatment with an essential oil of A. conyzoides (Pari et al., 2000) and C. rotendus (El-Sokkary, 2003). Some other authorities documented similar inhibitory action of various plant species on the metamorphosis of some insects while others reported no effect or even contradictory effects, depending on the activity of the plant species and the susceptibility of the insect (Shaurab et al.,1998; Ghoneim et al., 2000; Al-Dali et al., 2003).

Disrupted metamorphosis of $S$. gregaria by the action of $F$. bruguieri extracts, in the present study, was represented in the formation of some nymphal-adult intermediates. After treatment of the penultimate instar nymphs, the most effective $F$. bruguieri extract on such program was the petroleum ether one since the nymphaladult intermediate creatures appeared in a dose-dependent trend while 14.3 and $12.5 \%$ intermediates appeared at the concentration levels 7.5 and $3.7 \%$ of methanolic extract and $12.5 \%$ intermediates at the concentration level $15.0 \%$ of n-butanolic extract . After treatment of last instar nymphs with methanolic or n-butanolic extract, some nymphal-adult intermediates appeared at all concentration levels but only at the higher two concentration levels of petroleum ether extract. To a great extent, similar results had been obtained by Azt. in Bombyx mori (Koul et al., 1987), Spodoptera litura (Gujar and Mehrota, 1983), Aedes aegypti (Naqvi, 1986), M. domestica (Wilps, 1989) and for some other botanicals in M. stabulans (El-Shazly et al., 1996). 
The formation of nymphal-adult intermediates of $S$. gregaria, in the present study, possibly indicated the disturbance of the normal ecdysone or ecdysteroid titer which is usually needed for the perfect metamorphosis program or even the inhibition of neurosecretion (prothoracicotropic hormone) causing the inhibition of a number of physiological processes, such as metamorphosis ( Josephrajkumar et al., 1999). Also, the suggestion of Senthil Nathan et al. (2007) may be appreciated because the feeding of $N$. lugens nymphs on neem-treated plants for some days resulted in damage to physiological processes essential to metamorphosis. However, further investigation should be conducted in future to disclose this questionable issue and ascertain the mode of action of possible active components contained in F. bruguieri.

\section{REFERENCES}

Abdel-Ghaffar, A. A.; Ghoneim, K. S.; Tanani, M. A.; Bream, A. S. and Nassar, M. I. (2008). Developmental responses of the red palm weevil Rhynchophorus ferrugineus to some plant extracts. J. Egypt. Acad. Soc. Environ. Develop., 9(1): $11-25$.

Akhtar, Y. and Isman, M. B. (2004). Comparative growth inhibitory and antifeedant effects of plant extracts and pure allelochemicals on four phytophagous insect species. J. Appl. Entomol., 128: 32 - 38.

Al-Dali, A. G.; Abdel-Ghaffar, A. and Ghoneim, K. S. (2003). Efficacy of the neem seed extract, Margosan-0, on the developmental and morphogenesis of Muscina stabulans (Diptera: Muscidae). J. Egypt. Ger. Soc. Zool., 42:85-100.

AliNiazee, M. T.; Al-Humeyri, A. and Saeed, M. (1997). Laboratory and field evaluation of a neem insecticide against Archips rosanus L. (Lep., Tortricidae). Can Entomol., 129: 27 - 33.

Al-Sharook, Z.; Balan, K.; Jiang, Y. and Rembold, H. (1991). Insect growth inhibitors from two tropical Meliaceae: effect of crude seed extracts on mosquito larvae. J. Appl. Entomol., 111: 425 - 430.

Amer, M. S. ; Ghoneim, K. S. ; Al-Dali, A. G. ; Bream, A. S. and Hamadah, Kh. Sh. (2004). Assessment of the activity of Margosan-0 and Jojoba against the house fly Musca domestica (Diptera: Muscidae). Al-Azhar Bull. Sci., 15(2): 9 - 24.

Ammar, M. and N'cir, S. (2008). Incorporation of Cestrum parquii (Solanaceae) leaves in an artificial diet affected larval longevity and gut structure of the desert locust Schistocerca gregaria. Tunisian J. Plant Protec., 3: 27 - 34.

Armbruster, P. and Hutchinson, R. A. (2002). Pupal mass and wing length as indicators of fecundity in Aedes albopictus and Aedes geniculatus (Diptera: Culicidae). J. Med. Entomol., 39: 699 - 704.

Athanassiou, C. G.; Kontodimas, D. C.; Kavallieratos, N. G. and Veroniki, M. A. (2005). Insecticidal effect of NeemAzal against three stored product beetle species on rye and oats. J. Econ. Entomol., 98: 1733 - 1738.

Barbouche, N. (2001). La physiologie du développement et de la reproduction de Schistocerca gregaria Forsk. 1775 (Orthoptera : Acrididae) et les modalités de leurs perturbations sous l'action de different régimes alimentaires. Doctorat d'Etat en sciences agronomiques. Institut National Agronomique de Tunisie, Tunisia, $150 \mathrm{pp}$.

Benaag, A.; Honda, H. and Shong, T. (1997). Effects of alkaloids from Yam Dioscorea hispada on larvae of the diamondback Moth, Plutella xylostella (Lepidoptera: Yponomeutidae). Appl. Entomol. Zool., 32: 119 - 126. 
Boughdad, A., Kane, C.M.H., and Sy, A. (2005). Méthodes alternatives de contrôle du croquet pèlerin dans une aire de rémission en Mauritanie. 9 p. In : AFPP-7e Conf. Intern. Sur les Ravageurs en Agriculture. Octobre 26 et 27, Montpellier, France.

Cespedes, C. L.; Salazar, J. R.; Martinez, M. and Aranda, E. (2005). Insect growth regulatory effects of some extracts and sterols from Myrtillocactus geometrizans (Cactaceae) against Spodoptera frugiperda and Tenebrio molitor. Phytochem., 66: 2481-2493.

Crosby, D. G. (1995). Environmental fate of pyrethrins. In "Pyrthrum Flowers: Production, Chemistry, Toxicology and Uses" (eds: Casida, J. E. and Quistad, G. B.). Oxford Press, New York, Pp: $177-178$.

Darvas, B.; Polar, L. A.; Bream, A. S.; Castlos, I.; Farag, A. I.; Toroma - Gazdag, M.; Uonal, Z.; Calcogno, M. P. and Toledana, T. C. (1996). Efficacy of Ajuga (A. chamaepitys, $A$. reptans var reptans, and var atropurpurea ) extracts on a wide variety of non-adapted insect species. In "Neem and Environment", 2: 1085 1100, Oxford \& IBH Pub. Co. PVT Ltd., New Delhi.

Dempster, C. (1957). The population dynamic of moroccan locust Dociostarus murcocamus in Cyprus. Anti Locust Bull., 27.

Dorow, E. (1993). Present practices of controlling desert locust outbreaks. In: "New strategies for locust control". (ed.: Rembold, H.) ATSAF. Bonn., 89:7-8.

El-Sokkary, Z. F. A. (2003). Biological and physiological effects of some insect growth regulators and botanicals on the desert locust Schistocerca gregaria Forskal. Unpublished M.Sc. Thesis, Fac. Sci., Ain Shams Univ. Cairo, Egypt.

El-Gammal, A. M.; Karrar, A. H.; Mohamed, M. T. and Ghoneim, K. S. (1988). Antifeeding effects of some wild plants in the Eastern desert of Egypt and Sudan to Schistocerca gregaria Forskal (Orthoptera: Acrididae). J. Fac. Educ., Ain Shams Univ., 13: 251-262.

El-Shazly, M. M.; Nassar, M. I. and El-Sherief, H. A. (1996). Toxic effects of ethanolic extract of Nerium oleander (Apocynaceae) leaves against different developmental stages of Muscina stabulans (Diptera). J. Egypt. Soc. Parasitol., 26(2): $461-473$.

El-Sherief, H. A. (1998). Life table analysis of Spilostethus pandurus (Scopoli) (Hemiptera:Lygaeidae) treated with azadirachtin and cyphenothrin (Gokihlat): a comparative study. J. Egypt Ger. Soc. Zool., 27(E): 207-219.

Franzen, II. (1993). Need for development of new strategies for locust control. (ed.: Rembold, H.) ATSAF. Bonn., 89:9-13.

Georges, K.; Jayaprakasam, B.; Dalavoy, S. S. and Nair, M. G. (2006). Pest-managing activities of plant extracts and anthraquinones from Cassia nigricans from Burkina Faso. Biores. Tecn., 99: 2037-2045.

Ghoneim, K. S.; Mohamed, H. A. and Bream, A. S. (2000). Efficacy of the neem seed extract Neem Azal on the growth and development of the Egyptian cotton leafworm, Spodoptera littoralis Boisd. (Lepidoptera: Noctuidae). J. Egypt. Ger. Soc. Zool., 33: $161-179$.

Ghoneim, K. S. and Abdel-Ghaffar, A. A. (2007). Effectiveness of certain plant extracts on transaminase activities of the house fly Musca domestica (Diptera: Muscidae). J. Biol. Pharm. Sci., 5(1): 1-12.

Ghoneim, K. S. and Al-Dali, A. G. (2002). Survival and reproductive responses of Muscina stabulans Fallen (Muscidae: Diptera) to the neem seed extract, Margosan-0. Proc. $2^{\text {nd }}$ Int. Conf., Plant Prot. Res. Inst. Cairo, Egypt, 21-24 Dec. 
Gruys, P. (1993). Leçon à tirer du dernier fléau du criquet pèlerin 1986-1988. Pages 19-30. Compte-rendu du séminaire sur la lutte contre le criquet pèlerin par les techniques existantes.

Guendous-Benrima, A. (2005). Ecophysiologie et biogéographie du criquet pèlerin, Schistocerca gregaria Forsk. 1775 (Orthoptera: Acrididae) dans le Sud algérien. Doctorat d'Etat en sciences agronomiques, Institut National Agronomique d'El Harrach, Algeria, $210 \mathrm{pp}$.

Gujar, G. T. and Mehrotra, K. N. (1983). Biological activity of neem against the red pumpkin beetle, Aulacophora foveicollis. Phytoparasitica, 16: 293 - 302.

Huang, Y.; Lam, S. L. and Ho, S. H. (2000). Bioactivities of essential oil from Elettaria cardamomum (L.) Maton. to Sitophilus zeamais Motschulsky and Tribolium castaneum (Herbst). J. Stored Prod. Res., 36: 107-117.

Hunter-Jones, P. (1961). Rearing and breeding locusts in the laboratory. Bull. Antilocust Res. Center London, $12 \mathrm{Pp}$.

Jacobson, M. (1989). Botanical pesticides, past, present and future. In: "Insecticides of plant origin". (Arnason, J. T., ed.). Proc. Amr. Chem. $\alpha$ Soc. Washington, D. C.:1- 10 .

Jagannadh, V. and Nair, V. S. K. (1992). Azadirachtin-induced effects on larval-pupal transformation of Spodoptera littoralis. Physiol. Entomol., 17: 56 - 61.

Jbilou, R.; Amri, H.; Bouayad, N.; Ghailani, N.; Ennabili, A. and Sayah, F. (2008). Insecticidal effects of extracts of seven plant species on larval development, $\alpha$ amylase activity and offspring production of Tribolium castaneum (Herbst) (Insecta: Coleoptera: Tenebrionidae). Bioresource Technol., 99: 959 - 964.

Josephrajkumar, A.; Subrahmanyam, B. and Srinivasan (1999). Plumbagin and azadirachtin deplete haemolymph ecdysteroid levels and alter the activity profiles of two lysosomal enzymes in the fat body of Helicoverba armigera (Lepidoptera: Noctuidae). Eur. J. Entomol., 96: 347-353.

Koul, O.; Amanai, K. and Ohtaki, T. (1987). Effects of azadirachtin on the endocrine events of Bombyx mori. J. Insect Physiol., 33: 103-108.

Linton, Y. M. ; Nisbet, A. J. and Mordue, A.J. (1997). The effects of azadirachtin on the testes of the desert locust, Schistocerca gregaria (Forskal). J. Insect. Physiol., 43 (11): 1077 - 1084.

Meisner, J.; Ascher, K. R. S.; Aly, R. and Warthen, J. D., Jr. (1981). Response of Spodoptera littoralis (Boisd.) and Earias insulana (Boisd.) larvae to azadirachtin and salannin. Phytoparasitica, 9: $27-32$.

Meisner, J. ; Melamed-Madjar, V. and Nemny, N. E. (1991). Effect of Margosan-0 on the growth and development of Osterina nubilalis. Int. Pestic. Control ( $c f$. Meisner and Nemny, 1992).

Miller. J. A. and Chamberlain, W. F. (1989). Azadirachtin as a larvicide against the horn fly, stable fly, and house fly (Diptera: Muscidae). J. Econ. Entomol., 82 (5): $1375-1378$.

Mohamed, H. A.; Bream, A. S. and Ghoneim, K. S. (2000). Developmental and reproductive responses of the house fly Musca domestica (Diptera: Muscidae) to the neem seed extract, Neem Azal. J. Egypt. Ger. Soc. Zool., 31:235- 249.

Mordue, A. J. and Evans, K. A. (1987). The physiological effects of azadirachtin on the locust, Locusta migratoria. Proc. $6^{\text {th }}$ Int. Symp. Insect-Plant Relationships, (eds.: V. Labeyrie, G. Fabres and D. Lachaise) Pp: 43 - 48. Pudoc, Wageningen.

Moroney, M. J. (1956). Facts from figures ( $3^{\text {rd }}$ ed.). Penguin Books Ltd., Harmondsworth. Middle Sex. 
Muse, W. A.; Lajide, L. and Adedire, C. O. (2003). Effects of some Nigerian plants on survival, oviposition, and emergence of adult blowfly, Chrysoma chloropyga (Wied.) (Diptera: Calliphoridae). J. Asia-Pacific Entomol., 6(1): $69-75$.

Naqvi, S. H. (1986). Biological evaluation of the fresh neem extracts and some neem compounds, with reference to abnormalities and esterase activity in insects. Proc. $3^{\text {rd }}$ Int. Neem Conf., Nairobi, Pp: $315-330$.

Nascimento, I. R.; Murata, A. T.; Bortoli, S. A. and Lopes, L. M. (2004). Insecticidal activity of chemical constituents from Aristolochia pubescens against Aticarsia gemmatalis larvae. Pestic. Manag. Sci., 60: 413- 416.

Nasiruddin, N. and Mordue (Luntz), A. J. (1994). The protection of barley seedlings from attack by Schistocerca gregaria using azadirachtin and related analogues. Entomol. Exp. Appl., 70: 247 - 252.

Nicol, C. M. Y. and Schmutterer, H. (1991). Contact effects of seed oil from the neem tree Azadirachta indica (A. Juss.), on nymphs of the gregarious phase of the desert locust, Schistocerca gregaria (Forsk.). J. Appl. Entomol., 111 (2): $197-205$.

Olaifa J. L. and Akingbohungbe, A. E. (1986). Antifeedant and insecticidal effects of extracts of Azadirachta indica, Petiveria alliacea and Piper guineense on the variegated grasshopper, Zonocerus variegatus. Proc. 3rd Int. Neem Conf. Nairobi., pp: 405- 418.

Osman, M. Z. (1993). Effects of neem seed extract on growth and development of larvae of Pieris brassicae L (Lep.: Pieridae). J. Appl. Entomol., 115: 254-258.

Pari, K. ; Subrahmanyam, B.; Rastogi, J. N.; Devakumar, C. and Rao, P. J. (2000). Insecticidal $(Z)-6$ - methyl - 12 - heptadecenoic acid from the essential oil of Ageratum conyzoides. Indian J. Chem. (Sec. B), 39 (6): 451 - 454.

Quadri, S. S. H. and Narsalah, J. (1978). Effect of azadirachtin on the moulting process of last instar nymphs of Periplanetta americana Linn. Indian J. Exp. Biol., 16: 1141.

Rembold, H. (1994). Advances in Invertebrate Reproduction. Elsevier Sci. Publishers., 3: $481-491$.

Richards, A. G. (1957). Cumulative effects of optimum and suboptimum temperatures on insect development. In "Influence of Temperature on Biological Systems" ( Johnson, F. H., ed.). Amr. Physiol. Soc., 15: 35 - 38.

Saxena, R. C. (1987). Antifeedants in tropical pest management. Insect Sci. Applic., 8: $731-736$.

Saxena, R. C. and Khan, Z. R. (1985). Effect of neem oil on survival of Nilaparvata lugens (Homoptera: Delphacidae) and on grassy stunt and ragged stunt virus transmission. J. Econ. Entomol., 78: 647 - 651.

Saxena, R.C.; Harshen, V.; Saxena, A.; Sukumaran, P.; Sharma, M. C. and Lakshamana Kumar, M. (1993). Larvicidal and chemosterilant activity of Annona squamosa alkaloids against Anopheles stephensi. J. Amr. Mosq. Cont. Assoc., 9(1): 84 - 87.

Schmutterer, H. (1995). The neem tree Azadirachta indica A. Juss. and other Meliaceous plants. VCH Publishers, Wcinhcim, Germany. p: 696.

Schmutterer, H. ; Baumgart, M. ; Freisewikel, D. Langenwald, J. and Nicol, C. M. Y. (1993). The effects of neem oil and other neem products on nymph and resulting adults of Schistocerca gregaria, Nomadacris septemfasciata, Locusta 
migratoria migratorioides and Zonocerus variegates. J. Appl. Entomol., 116 (2): $178-186$.

Schmutterer, H. and Freres, T. (1990). Influence of neem-seed oil on metamorphosis, colour and behaviour of the desert locust Schistocerca gregaria (Forsk.) and the African migratory locust Locusta migratoria migratorioides (R. \& F.). Zeitschrift Fur Pflanzenkrankheiten Und Pflanzenschutz., 97 (4): 431 - 438.

Senthil Nathan , S.; Kalaivani, K. and Sehoon K. (2006). Effects of Dysoxylum malabaricum Bedd. (Meliaceae) extract on the malarial vector Anopheles stephensi Liston (Diptera: Culicidae). Bioresource Technol., 97: 2077 - 2083.

Senthil Nathan, S. (2006). Effects of Melia azedarach on nutritional physiology and enzyme activities of the rice leaffolder Cnaphalocrocis medinalis (Guenée) (Lepidoptera: Pyralidae). Pestic. Biochem. Physiol., 84: 98-108.

Senthil Nathan, S.; Choi, M. Y. ; Paik, C. H. ; Seo, H. Y. ; Kim, J. D. and Kang, S. M. (2007). The toxic effects of neem extract and azadirachtin on the brown planthopper, Nilaparvata lugens (Stal) (Homoptera: Delphacidae). Chemosphere, 67: $80-88$.

Sharda, S. ; Rao, P. J. and Singh, S. (2000). Effects of Ageratum conyzoides on feeding, development and reproduction of Schistocerca gregaria (Forskal). Pestic. Res. J., 12 (2): $204-209$.

Shaurub, E. S. H.; Ahmed, Z. A. and El-naggar, S. E. M. (1998). Impacts of pyriproxyfen and extract of Schinus terebinthifolius Raddi on development, reproduction and reproductvie organs in Spodoptera littoralis (Boisd.) (Lepidoptera: Noctuidae). J. Egypt Ger. Soc. Zool., 27(E): 57-82.

Showler, A. T. (1995). Desert locust control, public health, and environmental sustainability in North Africa. In: "The North African environment at risk". (eds.: W. D. Swearingen and A. Bencherifa), West view Press, Boulder, CO., USA., pp. 217-239.

Sieber, K. P. and Rembold, H. (1983). The effects of azadirachtin on the endocrine control of moulting in Locusta migratoria. J. Insect Physiol., 29(6): 523 - 527.

Siriwattanarungsee, S.; Sukontason, K. L.; Olson, J. K.; Chailapakul O. and Sukontason, K. (2008). Efficacy of neem extract against the blowfly and housefly. Parasitol. Res., 103: 535 - 544.

Sugavanam, B. and Copping, L. G. (1998). Development of crop protection agentsinvention to sales. In "Pesticide Formulation: Recent Developments and their Applications in Developing Countries. (eds: van Valkenburg, W.; Sugavanam, B. and Khetan, K. S.). New Age Integument. Limited Publishers, New Delhi, India, pp. $3-29$.

Uri shalom; Applebaum, S. W. and Pener, P. M. (1988). Vitellogenesis and oocyte development in azadirachtin induced fifth-instar overage nymphs of Locusta migratoria. Arch. Insect. Biochem. Physiol., 9: 313 - 322

von Elling, K.; Borgemeister, C.; Setamou, M. and Poehling, H. M. (2002). Effect of Neemazal-T/S, a commercial neem product, on different developmental stages of the common greenhouse whitefly Trialeurodes vaporariorum Westwood (Hom., Aleyrodidae). J. Appl. Entomol., 126: 40 - 45.

Ware, G. W. (1982). Pesticides: Theory and application. Thompson publications, Freson, California., 308p.

Weathersbee III A.A. and Tang, Y. Q. (2002). Effect of neem extract on feeding, growth, survival, and reproduction of Diaprepes abbreviatus (Coleoptera: Curculionidae). J. Econ. Entomol., 95: $661-667$. 
Wen, J. H. and Schmutterer, H. (1991). Effects of extracts from fruit and leaves of Melia azedarach L. on Locusta migratoria migratorioides (R. \& F.). Anz. Schadlingskde. Pflanzenschutz Umweltschutz., 64: 128 - 133.

Wilps, H. (1986). Growth and adult molting of larvae and pupae of the blowfly, Phormia terraenovae in relationship to azadirachtin concentrations. Proc. $3^{\text {rd }}$ Int. Neem Conf. Nairobi, pp. 299-314.

Wilps, H. (1989). The effect of extracts from the neem tree Azadirachtin indica on flight activity, food uptake, reproduction and carbohydrate metabolism in the dipteran Phormia terraenovae (Dip., Muscidae). Zool. Johr. Abt. Fur. Allg. Zool., 93: 271 - 282.

Xiao Dong, L.; Zhao Shan, H.; Li, X. D. and Zhao, S. H. (1997). The insecticidal activities of extract from meliaceous plant leaves on Oxya chinesis. J. South China Agric. Univ., 18 (4): 47 - 51.

Yoshida, A. H. and Toscano, N. C. (1994). Comparative effects of selected natural insecticides on Heliothis virescens (Lepidoptera: Noctuidae) nymphs. J. Econ. Entomol., 87: $305-310$. 


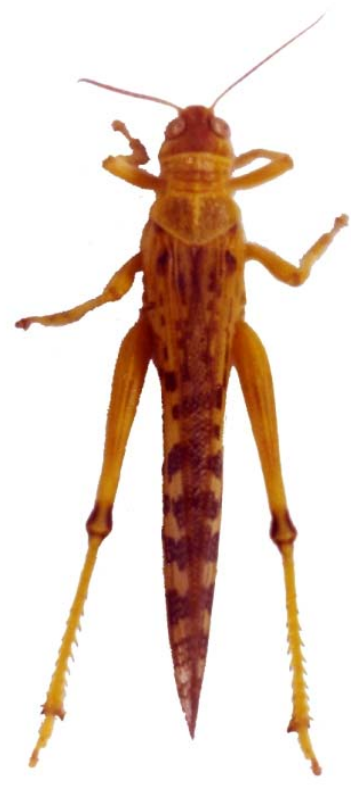

A

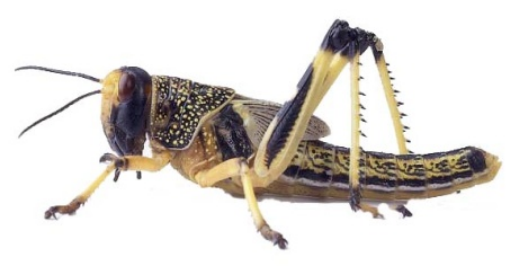

B

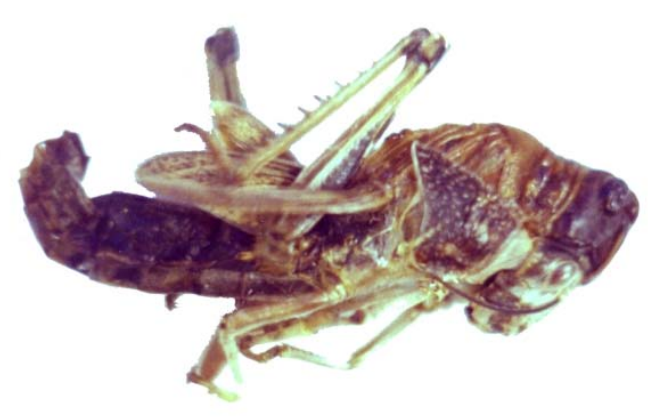

C

Plate (1): Nymphal-adult intermediates of Schistocerca gregaria as a result of disturbed metamorphosis program after the nymphal treatments with the Fagonia bruguieri extracts. A) Normal adult. B) Normal last instar nymph. C) a nymphal-adult intermediate. 


\section{ARABIC SUMMARY}

تأثر كل من الكفاءة المعيشية والإنماء بمستخلصات النبات البري فاجونيا بروجيري (الفصيلة الطرطراوية)

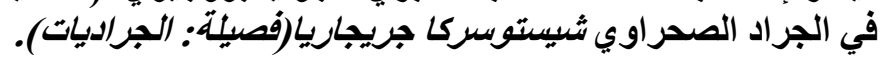

$$
\text { كارم السيّ غنيم - محمد علي طنية طناني ـ أحمد لطفي بسيوني }
$$

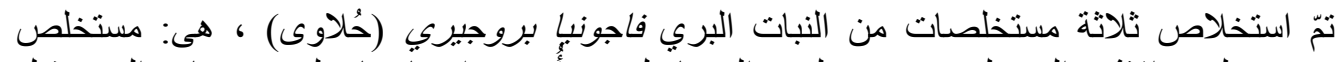

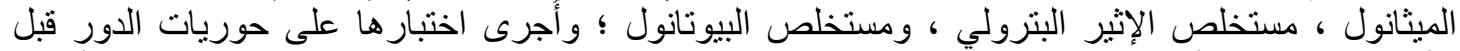

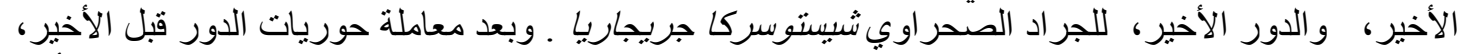

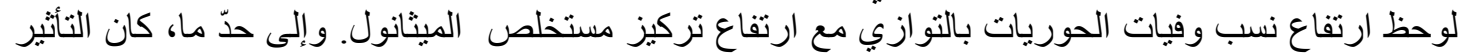

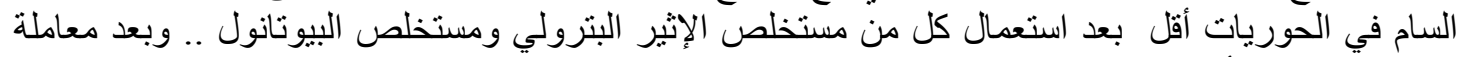

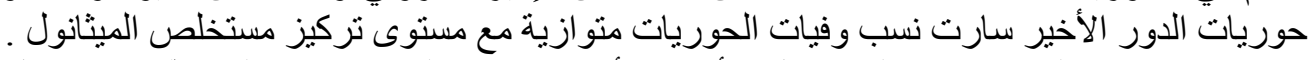

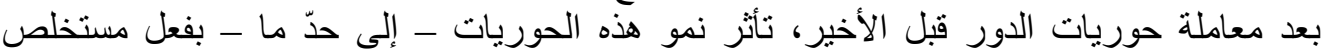

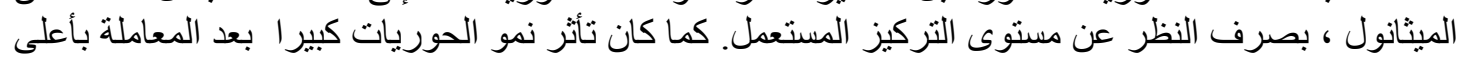

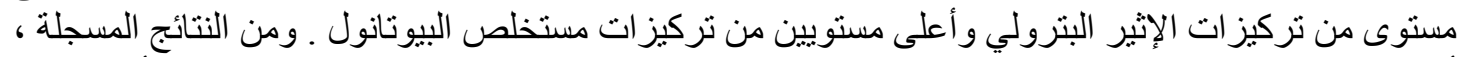

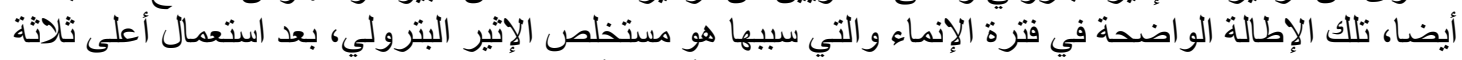

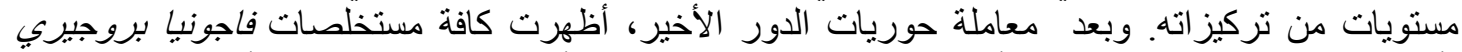

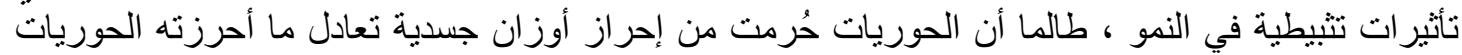

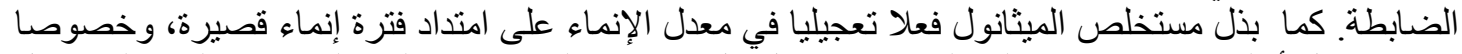

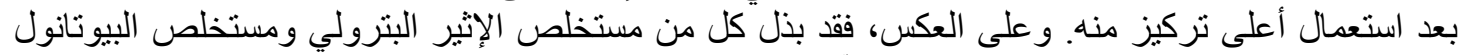

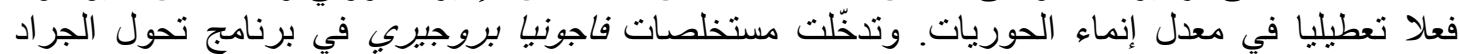
الصحر اوي، إذظهرت في أنكال وسيطة بين الحوريات ولئ واليافعات. 